\title{
Chariots of Fire Rerun: Locating Film's Cultural Capital on a Contemporary Stage
}

\begin{abstract}
The title sequence of Chariots of Fire - filmed on the West Sands beach of St Andrews, Scotland - has become one of the most reworked and reinterpreted moments of British cinema, transposed across a variety of places, politics and times. In exploring these moves from the period of its setting in 1924, through its production in 1980, and to its most recent reworkings in the London 2012 Olympics - the article examines the constantly evolving legacies of the sequence and the cultural capital it has accrued across these contexts. By considering the original production and subsequently its multiple receptions, the article positions the sequence at the vanguard of shifts in film production and cultural heritage. Viewed from the vantage point of the 2012 Olympics, the film provides an integral source of cultural capital not just for national but also local and regional economies as they increasingly target new sources of revenue in a post-industrial age.
\end{abstract}

Word count: 7977, including notes, references, captions and acknowledgements. 
Chariots of Fire Rerun: Locating Film's Cultural Capital on a Contemporary Stage

OPENING CREDIT TITLE

'CHARIOTS OF FIRE'

2 EXT. A BEACH. BROADSTAIRS, KENT. DAY

STILL ON THE FEET the sand flying - the wet - crunching through sea pools and driving rain.

Up the mud bespattered sockless calves - the pounding knees, the soaked, voluminous shorts - all-enveloping the pumping thighs ... the clenched piston fists, and finally, the punished faces.

CONTINUE CREDITS

[VOICEOVER]: Carlton Hotel Broadstairs ...

- Chariots of Fire screenplay (Welland 1980) 


\section{Cultural Capital on the Olympic Stage}

The title sequence of Chariots of Fire (1981) is perhaps the most iconic, and re-run, moment of British national cinema. Coming as the second scene in the film (and repeated again at the end), it flashes back from the film's opening in 1978 at the memorial service of renowned runner Harold Abrahams. From the service, the film cuts to 1924 when the British Olympic team, of which Abrahams was part, trained on the Broadstairs beach before crossing the channel to compete in the Games that summer in Paris. Binding together the film's heterogeneous snapshot of rivals, classes, ethnicities, and regions (England and Scotland in particular), the scene powerfully condenses the film's national allegory as it presents the inherent unity of the diverse team in their matching white, mud-speckled uniforms. To the strains of Vangelis's Academy-Award winning score, they run in slow-motion across the beach in two dramatic long-takes, the first a dolly shot in medium framing, the second a sweeping pan across the landscape in long shot with a town on the horizon. The scene's third shot then follows the runners off the beach and into the town. As they cross onto grass, the sign of Kent's Carlton Hotel appears, somewhat incongruously - incongruous because the scene was not shot in Broadstairs Kent, but rather in St Andrews, Scotland, some 600 miles north and identifiable through one of the world's most iconic sporting landscapes, the fairway of St Andrews's Old Course, internationally recognised as the 'Home of Golf'.

As a sequence which cinematically transposes geographies and times, the beach run has an enduring cultural power that we aim here to explore from its filming in St Andrews in 1980 to its repeated reworkings around the London 2012 Olympics. It has been renewed, pastiched and appropriated by local economies, national interests, and global industries (including Nike and Duracell), all deriving objectified cultural capital from the four-minute sequence. Our understanding of cultural capital derives from Pierre Bourdieu's tripartite theorisation of its embodied, objectified, and institutionalized forms. Embodied cultural 
capital pertains to how individuals incorporate 'long-lasting dispositions' of cultural knowledge into their minds and bodies, evidenced for instance through accents and manners; its objectified form encapsulates those cultural values concretised 'in material objects and media' and transmissible through their material form (e.g. the value of artworks); and its institutionalized aspect comprises those ideals that are granted authority by qualifying organizations, such as academic degrees bestowed by universities (Bourdieu 1986, 243-248). Bourdieu's original emphasis is largely on individuals and classes, for how they mobilize these forms cultural capital for economic self-interest. However, since the early 1980s, cultural capital, specifically in its objectified form, has become increasingly vital to postindustrial economies, as locales, nations, and international confederations have attempted to build, sustain, and re-monetize the outputs of cultural industries as heritage (see Throsby 2011; and Bandelj and Wherry, 2011). Our interest here is in how film has become embedded within this contemporary system as an objectified form of cultural capital in Britain, which we trace in relation to the rise of heritage cinema and film tourism since the 1980s. Tracking the movements and reworkings specifically of Chariots of Fire alerts us to the ways in which the film's cultural value has been renegotiated within fresh contexts over the past three decades.

The film's beach scene in particular continues to invite imitation and re-appropriation, and through this process the film as a whole, with all its complexities and tensions, has become condensed into a single iconic scene. Now often presented in isolation, due in no small part to its majestic score and visual sweep, the scene is open to an extraordinary range of allegorical meanings. Emblematic of a British heritage cinema that has been increasingly monetised for global audiences, the objectified value of the sequence as cultural capital was most recently and famously realised in the summer of 2012, as it was reworked multiple times and in multiple formats in London for the Olympic Games. At the opening ceremony, 
the sequence took centre stage as Sir Simon Rattle conducted the London Symphony Orchestra in 'a performance of Chariots of Fire'. This served not just as an orchestral performance of Vangelis' score, but more ambitiously as the announcer explained, as a 'tribute to the British film industry', in the context of the film's remarkable successes at the Academy Awards, Cannes, and the BAFTA awards when it was released. By 2012, the beach sequence had come to represent an internationally acclaimed and lucrative mode of British cinema, the heritage film, which dominated British production in the 1980s and 1990s and continues to flourish today (Higson 2003: 1-8; and Higson 2006).

The Games' opening ceremony reworked the sequence as a way to champion British cinema for a global audience, but through the performance it also simultaneously problematised the ideologies and politics of the film. The ceremony's Chariots homage begins in reverential terms, seemingly endorsing its celebrated status in the canon of British cinema, but this is soon undercut in the classic British tradition of self-mockery by the appearance of Rowan Atkinson as his famous and wordless alter ego Mr Bean, assuming the role of a pianist in the orchestra. Tasked with playing the same, single note of Vangelis's score on the keyboard, he grows increasingly bored and distracted, eventually escaping into a filmic dream sequence - directed by Danny Boyle and projected into the Olympic stadium as the orchestra continues the accompaniment. The dream transfers Mr Bean through the footage and music into the actual title sequence of Chariots of Fire, digitally grafting him like Forrest Gump into the original film as one of the runners, thus transposing his dream cinematically across space and time.

In placing Mr Bean into the scene, the sequence now reveals tensions between individual and national identity. Whereas in the original sequence the runners trained together collaboratively, projecting an allegory of national unity across the fissures of the film's class and ethnic conflicts, now Mr Bean competitively jostles with his other runners to move into 
the lead, first aided by a car and then resorting to tripping his fellow frontrunner, so that he can finish first, across a newly staged finish line filmed by Boyle in St Andrews in 2012. Given its original use, the restaged sequence becomes emblematic of an inclusive British identity simultaneously layered with Bean's competitive individualism. The layered temporalities of the performance - encapsulating the cultural politics of the London Olympics in 2012 filtered through a 1981 cold-war reimaging of the 1924 Games in Paris present a complex negotiation of post-imperial British identity, one that is still bound, culturally as well as economically, by the legacies and ceremonies of its past. Such a negotiation is a vital process for a nation attempting to promote the contemporary value of a cultural heritage that still contains the residue of its colonial past.

In a Games seemingly obsessed with legacy, London's opening ceremony serves as a legacy, or hangover, from British colonialism, an attempt to think through and come to terms with the country's post-imperial identity. It is fitting that this should be negotiated ceremoniously in London, in a form that so closely recalls the imperial exhibitions of the early twentieth century. In April 1924, a few months before the events depicted in Chariots, the largest of all exhibitions, the Empire Exhibition at Wembley, opened its gates letting in more than twenty-seven million visitors across its two seasons. The exhibition served as a microcosm of Empire, with the various colonies and dominions brought to London in the form of their individual pavilions, and each was defined by its national dress, flags and - as economic imperialism became the dominant form - consumer products (MacKenzie 1984: 96-120). While the Olympic opening, with its parade of flags through the stadium, retained much of the pomp and ceremony evident when Queen Elizabeth II's grandfather, George V, opened the Empire exhibition in 1924, the Queen's entrance in 2012 via helicopter with Daniel Craig as James Bond highlighted, just as Mr Bean had earlier in the evening, Britain's inability now to play it straight and an increasing blurring between Britain's traditional 
regency and modern culture. This blurring now sees the Queen repositioned alongside the hugely successful cultural exports of Bean, Bond, and Mary Poppins. The imperial splendours of 1924 - in territorial terms Britain's virtual apogee - could, it appears, not now be recalled without a heavy dose of irony as the cultural values objectified through these various icons are mobilised for national display. Alongside references to British immigration - most notably, the restaged 1948 arrival of West Indian immigrant workers on the steamship Empire Windrush - the Chariots clip becomes emblematic of a modern Britain, one that recalls and is indebted to its imperial past, but which now reworks the sequence's objectified cultural value ironically for a modern age.

The staging of this national allegory can also usefully be compared to the mass spectacles staged at the opening ceremonies of the Olympic Games recently (Beijing in 2008) and historically (Berlin in 1936) - both examples of which were also cinematic in fundamental ways, given the respective involvement of Zhang Yimou and Leni Riefenstahl. The London restaging of the Chariots scene forms a productive counterpoint to these prior ceremonies. In light of the economic downturn leading up to the 2012 Games and the resulting public debates over cost, the Chariots sequence to an extent undercuts the opulent grandeur of the mass spectacles associated with these earlier ceremonies. It certainly presents an inclusive, national image grounded in the original film, but rather than the ornamental mass structures of Berlin and Beijing, it is one that functions cinematically through psychologized modes of character identification as viewers can through the everyman of $\mathrm{Mr}$ Bean imagine themselves into the scene. The London performance simultaneously presents the participatory allegory while also parodying and vulgarising it through Bean.

Bean's parody, however, was not without its critics. As noted for instance in Digital Spy on 6 August 2012, the British composer Michael Nyman took the sequence to task in social media, first criticising the very inclusiveness of the ceremony - for performing music 
not 'by a British composer but by Vangelis, a Greek' - and then for 'subverting' the very nature of the original scene with $\mathrm{Mr}$ Bean. ${ }^{1}$ However, this process of subversion is in fact one of the means through which a film becomes recognisable and canonical, as it builds and sustains its objectified cultural capital through reuse and adaptability across time. An early example of this, which highlights the position of the Chariots sequence within global popular culture, can be found in the popular U.S. children's television show Sesame Street in 1983. The beach sequence - here renamed 'Chariots of Fur' and featuring two puppets, 'Grover old bean' and 'Harry old chap' running to the end of the beach - uses familiar points of reference: a close imitation of Vangelis's famous score, slow-motion movement, white tops, the beach. More significantly, the parody suggests that this isolated sequence was already emblematic of a particular version of British cinema and identity that was predicated on heritage and aristocratic values. Through the parody, however, these values are not taken quite at face value, a trend that has accelerated with each new adaptation. As the cultural politics of the heritage cycle have shifted since the 1980s, such parodies allow for a revision of the cultural inclusivity of the works. Indeed, it is this inclusivity that has factored into all of the recent adaptations and parodies of Chariots of Fire. For instance, when Britain's biggest selling newspaper, The Sun, presented a TV advertisement for the Olympics in 2012, it recreated the sequence but now showed a single runner, to the strains of Vangelis, joined on the beach by figures from all professions, class backgrounds, and ethnicities, using and adapting the film's theme of national unity to promote the paper's own credentials as a British institution. Featuring Nigel Havers, one of the actors from Chariots, to consolidate its connection to the film, the advertisement concluded with the tagline 'Let's make it Great, Britain'.2

Throughout the summer of 2012, the film itself was also contemporised through the London Olympics, enjoying a cinematic re-release after being digitally restored ('The Great 
British classic is coming back to the screen for a lap of honour') while also being adapted for the West End stage. The opening sequence on stage, again to Vangelis's music, featured runners in 2012 Team GB running kits, self-contained and removed from the narrative. The play thus made explicit the connection between the narrative events of 1924 , the cinematic response of 1980 and the contemporary Games, as a now firmly established transhistorical national allegory, adaptable across various historical moments. Beyond this, the stage example hints again at the ways in which the beach sequence has come to stand apart from the film. Yet, taken out of context as it so often is, the sequence obfuscates the complex struggles at the heart of the film: the role of nation in Eric Liddell's struggle between running for himself, his country, or his God; Harold Abrahams's desire to win at all costs (in hiring a discredited professional trainer of Italian-Turkish descent), an idea that clearly translates from 1924 to the boycotted Moscow Olympics of 1980 to 2012. While these aspects may sit less comfortably within the idealised national allegory, they astutely complicate the myth espoused within the beach sequence. Ultimately, these conflicts are rather conveniently resolved within the film's narrative - both Abrahams and Liddell can emerge as gold-medal winners, not having to confront one another competitively at the Games - which justifies the allegorical return of the beach sequence at the film's end. In this way, the appearance of $\mathrm{Mr}$ Bean within the reworked 2012 sequence, rather than just vulgarising the film, also reinserts its complexities and tensions back into the sequence when seen in isolation.

Such recent reworkings of Chariots of Fire point to the ways in which film's cultural capital has grown increasingly pronounced in the global economy, as governments, local councils, tourist boards, and independent cultural groups jostle to exploit and monetise onscreen appearances as well as attract film crews and tourists to their towns and cities. The hugely competitive Olympic bidding process - and the prominence now placed on its opening ceremony, viewed in 2012 by an estimated worldwide television audience of 900 
million - is indicative of the increasingly mediatised nature of the post-industrial cultural economy. The British government recently, and somewhat speculatively, claimed a $£ 9.9$ billion boost in trade and investment deriving from the tourism and media culture surrounding the Games. ${ }^{3}$ Relatedly, the example of Chariots of Fire also illustrates the cultural benefits now accruing to local and regional economies. Curiously enough, in this example, film heritage has been mined and localised far more prominently in St Andrews than in Broadstairs. Across this on-screen geographical displacement, the film and specifically the beach sequence have become enmeshed in the St Andrews imaginary much more so than in Kent, to the extent that the sequence has become a vital and localised form of cultural capital for the town of St Andrews. In this process, the film's regenerating allegory becomes embedded within overlapping local and national contexts, as the myriad of interests - whether global, national, or local - attach themselves to the sequence and attempt to extract, and in turn subtly reconfigure, its objectified cultural capital. Moreover, the shifting attitudes and approaches of local businesses, councils, and the public in St Andrews to the sequence from its initial filming in April 1980 to its recent frequent reuse as part of the town's heritage industry - illustrate the increasing prominence of film within the economies of post-industrial towns and cities over the last thirty years.

\section{Localising Cultural Capital}

Producer David Puttnam recently recalled in an interview an early screening of Chariots of Fire. At the conclusion of the film's opening beach sequence - as the camera pans beyond the sea and sand, beyond the scripted 'mud bespattered sockless calves' and 'piston clenched fists' to reveal the town of St Andrews, doubling as Broadstairs, Kent - Puttnam received a tap on the shoulder. On turning around, Puttnam was face to face with Sean Connery, who was initially approached to star in the film, and who has also held a long association with $\mathrm{St}$ 
Andrews. Recognising the world famous Old Course of the town, and unimpressed by this territorial transposition, Connery whispered to Puttnam, 'That's not the Carlton Hotel'. ${ }^{4}$

Sean Connery's observation attests to a wider recognition on the part of (particularly local) audiences of St Andrews's place through Chariots of Fire within recent British film history. This place is, of course, manufactured and artificial, symptomatic of cinema's role in transposing and replacing locations on screen. In the same interview, Puttnam suggested that filming in St Andrews was to an extent 'happenstance' with the town selected, as is often the case, for economic reasons. As filming was taking place in Crieff and Edinburgh, the production looked to 'consolidate locations' and find a suitable site in Scotland for the opening Broadstairs run. ${ }^{5}$ Whatever the chance reasons for this transposition, the landscape selected - the West Sands of St Andrews - would help to shape a heritage cycle that would do so much to define and revitalise the British film industry over the next decade. What's more, it is this emphasis on landscape in particular - as amplified by the pictorialist camera techniques of the heritage genre - that has enabled contemporary British cinema to draw attention to heritage sites, which in turn has fostered increased film tourism over the past two decades (Martin-Jones 2009: 14-16; Martin-Jones 2014; Street 2009: 116-117). It is through these complex moves - enmeshing the landscapes of heritage cinema within the broader heritage industry - that the objectified nature of film's cultural capital becomes useful for national, as well as local and regional, economies. The landscape of St Andrews in Chariots of Fire is a vital example of these recent developments in cultural economy.

The West Sands is a setting particularly rich in pictorial history, which even prior to Chariots of Fire accrued cultural value for St Andrews. As Robert Crawford has detailed recently, in the 1840s St Andrews was the first town in the world to be thoroughly documented photographically, helping through its sublime gothic ruins to ground the early memento-mori aesthetic of the new medium (Crawford 2011: 1). Within this rich 
iconography, the West Sands was one of the town's earliest landscape subjects to be photographed, ca. 1843, through a series of calotypes by the early photographic partners David Octavius Hill and Robert Adamson (Crawford 2011: 35). Images of the West Sands, from Hill and Adamson's photographs through postcards and other publicity materials still in use today, have helped promote the town's international identity. With the Old Course in the distance and the ruins and monuments of the town visible along its northern cliff, the iconography of the beach doubles to celebrate the town's most lucrative tourist industry of golf while also emphasising its equally famous medieval ruins.

The repositioning of this landscape at the forefront of British heritage cinema draws on this long history of the West Sands while also revitalising its contemporary cultural value for the town. Returning to the film sequence itself, the gothic sublime of the landscape is magisterially deployed in the opening of Chariots of Fire through its crosscutting and sound bridges. Uncannily moving from Abrahams's funeral to the height of his youthful vigour in 1924 on the beach, the dissolve to the past is preceded by the opening shofar-like horns of Vangelis's score, wafting in over the oration by Lord Andrew Lindsay, one of the two surviving 1924 Olympic runners, along with Aubrey Montague, at the funeral. Lord Lindsay's call of remembrance - that he and Montague 'can close our eyes and remember those few young men with hope in our hearts and wings on our heals' - invokes both death and rebirth through the backward glance that then materializes on the West Sands. The gothic sublime inherent to St Andrews landscape is thus used to ground the opening of the film within the specifics of a British national aesthetic centred in gothic Romanticism, a pictorialist technique that was invoked with increasing frequency in the British heritage cycle. In this way, the sequence's mise-en-scène would come to acquire objectified value as cultural capital both in cinematic terms, challenging American cultural imperialism by reimagining a British aesthetic that would become a model for the heritage cinema of the 1980s, and also 
for the town of St Andrews by promoting a local cultural economy, predicated on heritage and tradition.

Following on from the international success of Chariots of Fire, today the tourist industry of St Andrews - through its hotels, bars, tourist boards, University, and charities has sought to re-localise the landscape of the film, both in explicit reference and in restagings, as an integral part of the town's cultural capital. This was, again, evident around the Summer Olympics of 2012, as the Torch Relay diverted through St Andrews and included an early morning recreation of the Chariots sequence along the West Sands beach. The beach run, as reported by Fife Today on 3 August 2012 was now performed by local schoolchildren and was filmed from the same spot as in Chariots by BBC news crews (who inevitably included Vangelis's soundtrack). ${ }^{6}$ In the same year, the University of St Andrews produced a feature length film Ever to Excel, to memorialise its $600^{\text {th }}$ anniversary, and in it, reworked the beach sequence with a female cast of runners. These two examples reveal the local ways in which institutions have reworked Chariots of Fire. The school children served to propagate the legacy message of the London Olympics, whereas the University now reworked the sequence, at once, to celebrate its heritage - exporting the image of Oxbridge elites in the initial sequence to St Andrews - while simultaneously presenting itself as a progressive institution, as one of the first in Britain to include female undergraduates.

Significantly, the Olympic torch did pass through Broadstairs, but it was not taken onto the beach nor were any of the historical events depicted in Chariots of Fire emphasised. In the popular imagination, St Andrews has now claimed this history, re-enforcing the connection through regular screenings of the film, various other restagings of the sequence for example, an annual charity run in period costume on the West Sands beach - and through official markers, such as a national heritage plaque commemorating the film shoot, albeit one marked with the incorrect date. St Andrews's businesses and hotels also exploit the sequence 
commercially, emphasising local connections in publicity materials and even naming hotel rooms after the film. A local pub, 'Chariots Bar', is decked out with portraits of prominent Scottish figures, the most conspicuous of which is a mural of the film's protagonist Eric Liddell in Olympic running kit at the bar's entrance overlooking the West Sands beach.

The awareness and interest in film as cultural capital both within St Andrews and throughout Scotland has escalated during the last few decades, a move that can be traced back to Chariots of Fire. Though one might assume that this form of objectified cultural capital, connected as it is to cultural heritage, would exist naturally within post-industrial economies of the last half-century, this is, in fact, a more recent phenomenon with film. A closer examination of the filming in St Andrews on 24 April 1980 highlights the significant shifts in attitude in the last thirty years towards the industrial as well as cultural value of film production. This can be seen, for instance, in the reactions of the townspeople to the shoot. One extra, quoted in the local paper The Citizen on 3 May 1980, explained that most of his fellow extras 'had been offered the chance to be a film star for the day in local bars the night before'. The more athletic extras - those not found in the late night bars of St Andrews were brought together by Donald Macgregor, who had finished seventh in the marathon at the 1972 Olympics and was then working at the local secondary school, Madras College. Macgregor was approached by journalist Sandy Sutherland in late 1979 and tasked with assembling a team from the University cross-country runners and Fife Athletics Club. Despite his efforts in recruiting the extras and his own Olympic credentials, Macgregor surprisingly declined to take part himself in the actual run, explaining that he was reluctant to take a day off work (Macgregor 2010: 296).

If Macgregor was reluctant to leave the classroom for the film shoot, other locals were even more reticent - and in some cases resistant - to the presence of a film crew within the town. Shortly after the filming, Regional Councillors spoke out against the disruption caused 
by the shoot. The main complaint centred on the 'fact that Links Place was closed to traffic for a few minutes' during the shoot on the Old Course. Regional Councillor Tony Jackson told The Citizen on 3 May 1980 that 'he personally objected very strongly to time being wasted helping film people' and did not appreciate roads being closed for a 'frivolous reason'. The mood of the council was likely not improved by news that the film crews would have to return to St Andrews for additional filming on Thursday 1 May, a week after the initial shoot, as the original negative was scratched when sand got into the camera. ${ }^{7}$

Despite the initial reactions of the council towards the shoot, not all in St Andrews were negative about the production: The Citizen commented on the additional income brought in to hotels, businesses, and shops over the few days that the production visited St Andrews. Some councillors as well acknowledged that the town could benefit from publicity upon the film's release. However, in hindsight both the opposition and relatively restrained support for the film within the town appears short sighted given the cultural capital that has since accrued locally through the film. This apparent short-sightedness is exactly the historical point: in the early 1980s, film tourism was not yet an established phenomena beyond Hollywood, and it is only with the post-industrial transformations that have occurred since that film tourism has become objectified as a vital component of cultural capital, for not just national but also local and regional economies. The reactions in St Andrews to the Chariots shoot thus illustrate the seismic shifts in individual and institutional attitudes towards local film production in the intervening thirty years.

Chariots of Fire represents a vanguard for post-industrial economies, foregrounding the changing dynamics of local film shoots as part of cultural heritage. In presenting Britain to the world, Chariots promoted not products or goods but rather its national locations as a product in itself. The success of these moves, through the ensuing British heritage cycle, in turn spurred film tourism that has reinvigorated local and regional economies seeking to 
reclaim and localise their globally projected landscapes. Within Scotland, these shifts became more pronounced and organised during the 1990s. VisitScotland attributed a $£ 15$ million boost to tourism income on the back of Braveheart (1995) and Rob Roy (1995), further noting that visits to the Wallace monument increased more than three-fold between 1995 $(66,000)$ and 1997 (197,000) (Martin-Jones 2009: 68). ${ }^{8}$ More recently, VisitScotland has conducted a series of reports and surveys, in light of the Scottish government's financial support of Pixar's Scottish-set animated film, Brave (2012), through which VisitScotland sought to turn the international success of the film into tourist numbers to boost local businesses. In marked contrast to the production of Chariots of Fire in 1980 - 'happenstance' at best imagined as a fleeting boost to the town's economy - what we see today is a growing recognition and campaign on the part of the tourist industry, government, commercial bodies, and visitor agencies to bring film production to Scotland. Even the brief location filming of Never Let Me Go (2009) in St Andrews was overseen and celebrated by Tayscreen, which since 2002 has worked in partnership with local councils in Angus and Fife to promote the surrounding areas through film and media productions.

Chariots may have been at the forefront of the British heritage cycle, but it is largely through its afterlife - its global success, reuse and appropriation - that the beach sequence in particular has become culturally valuable to local and regional economies. This, in turn, has complicated its national allegory, as claims on the film's heritage are now contested between British and Scottish interests. Such contested claims are most evident around international sporting events. For instance, the Olympic Games, in noted contrast to the Commonwealth Games, envelops and self-imperialises the Home Nations within a British identity, as Northern Irish, Scottish and Welsh competitors perform in the British vest and under the British flag. The implications of this process hold particular resonance today in the context of debates around Scottish Independence. For example, the Scottish Football Association (SFA) 
and the Scottish National Party (SNP) vehemently opposed the formation of a GB football team for 2012, while more recently, SNP figures have controversially announced plans to enter a Scottish Olympic team at the 2016 Rio Games, should it achieve independence in the 2014 referendum.

The use of Chariots in the 2012 Olympic ceremony may then appear within this context as part of a longstanding process of unification, merging a Scottish location into the British Romantic imaginary. Yet, just as in the film's narrative, this remains an uncomfortable alliance, one that continues to be renegotiated by competing local and national interests. At the start of the 2012 Games on 27 July, SNP leader Alex Salmond announced in the Daily Record that Chariots of Fire would be made available to every school in Scotland, re-nationalising this 'British' film and using the story of Eric Liddell as part of the nationbuilding process within Scotland. ${ }^{9}$ While local regions and economies continue to rework the national allegory (whether celebrating St Andrews over Broadstairs, Scotland over England, or Britain over Europe and America), the cultural, economic, and promotional value of these moves is dependent on the continued international popularity and framing of the film, as the timing of Alex Salmond's announcement attests. This international context - then and now becomes imbricated with the film's local and national allegories, working through the spatial conflicts inherent in the text. Through the film, Britain, Scotland, and St Andrews each imagine a position on the international stage, initially through the text and then, in a move concretised by 2012, through the reclamation of the cultural capital of the film.

\section{'Made in Britain' for the Global Stage}

As we have traced, the beach sequence in Chariots of Fire has been pulled apart and reconstructed by local, national, and global interests throughout the last thirty years. It is through this process of recycling that the sequence accrues its cultural capital, building 
objectified value as competing interests become integrated within and stitched onto the scene. The beach sequence thus, at once, (re)places St Andrews, Scotland, and Britain within a constantly evolving allegory of national unity, a process that we have traced thus far in reverse, first from its recent reworkings during the 2012 London Olympics and then from the local reactions to, and shifting reception of, the sequence in St Andrews over the past three decades. Working further back now, we examine in this final section the initial, international reception of Chariots of Fire in relation to its pre-production and production contexts. Doing so will allow us to interrogate the film's own ideological stakes in cultural power. Its construction of and investment in a shared sense of 'Britishness' - which has been so useful to competing local and national interests over the past thirty years - was, in itself, a response to ongoing transformations of global power relations in the emerging cultural economy. Examining Chariots'specific cultural investments will clarify the reciprocal ways in which both local and national groups have reworked the film to administer power and authority on a global stage, not through militaristic force but increasingly through cultural influence.

To turn first then to the film's initial, international reception in March 1982: when Colin Welland collected the Academy Award for best original screenplay with Chariots of Fire, he famously announced 'The British are coming'. This oft-quoted remark is useful for illustrating Chariots' initial reception in distinctly nationalist terms, as a frontrunner of British heritage cinema. In echoing Paul Revere's famously misquoted line, Welland's speech also has a militaristic tone, uttered, as it was, only four days before the outbreak of the Falklands War. However, this militaristic context is to an extent misleading. While the Falklands War brought the ideology of Empire back to public attention, it also provided a stark reminder of what had changed. Britain's former might was now reduced to a protracted battle over an archipelago in the South Atlantic Ocean, as it attempted to recover its largely unacknowledged loss of prestige, influence, and imperial power. Instead of referring to the 
impending Falklands incursion, Welland's comments in fact signal a dramatic shift in the geopolitical conception of power, ironically now imagining British influence and power not in failed militaristic terms, but in cultural-economic terms at the emergence of the British heritage cycle. It is through film's cultural cachet, with Chariots at the fore, that Britain would attempt to recover and reorder a status dissipated in the post-World War II era of mass decolonisation.

Criticism of Chariots of Fire has yet to understand the specific ways in which the film itself reimagines post-industrial power through cultural capital, even as it seemingly harkens nostalgically back to the height of the British Empire in the 1920s. To understand how this works, it is important first to re-examine again the film's production context. In a recent interview, David Puttnam noted that the film shoot in St Andrews played out against the backdrop of an international crisis, which was visible on televisions in the local hotels and pubs throughout the production. ${ }^{10}$ April 24 1980, the day of the first shoot, was also the day of Operation Eagle Claw: the miserably failed American attempt to free the hostages held in the U.S. embassy in Teheran. President Jimmy Carter had initiated the rescue mission, but had to abort it after a number of the operation's helicopters broke down in the Iranian desert under adverse weather conditions. On the pull out, a crash occurred, killing eight soldiers.

No explicit reference to the emerging middle-east crisis can be found in Chariots of Fire, but its presence is felt obliquely through the film's emphasis on ethnic conflicts and racism during the interwar period: through the anti-Semitism that Abrahams faces in the film, and also through Abrahams's trainer Sam Mussabini, who was of Arab, Turkish, French, and Italian descent, though mentioned only as Italian-Arab in the film itself, to the clear displeasure of Abrahams's Cambridge deans. It is this minoritarian and quasi-professional collaboration between Abrahams and Mussabini that is one of the major problematics of the film, though one that the film cautiously downplays through the casting and performance of 
Ian Holm as Mussabini, relatively muting his racial features. Also given the 1920s setting, at the height of the British Empire, it would not have been lost on the filmmakers that the Iranian revolution was in no small way a result of Britain's political manoeuvres in Iran, from its hand in the 1921 coup that established the Pahlavi dynasty to the overthrow of Mosaddegh in 1953 through Operation Ajax, jointly run by MI5 and the CIA. The post-imperial themes being crafted into the film of solidarity - across national, ethnic, and global conflicts - would have thus resonated with the ruins of empire so visible in Scotland on the international news in the late spring of 1980 .

At a moment when British and American military power was so visibly exposed, Chariots offers a contemporary response both to the international crisis and, moreover, to Britain's crumbling position in the post-imperial world. In presenting its message of solidarity across racial and class lines, the film dislocates British influence from American power, and for this the Olympic setting provides an apposite context. In April 1980 shortly before filming began in St Andrews, the U.S. Olympic Committee ratified President Carter's boycott of the Moscow Olympics, a protest against the Soviet invasion of Afghanistan. In subtle but significant contrast in London a few weeks earlier, the House of Commons had also passed a motion stating that Great Britain 'should not take part' in the Games. However, in Britain unlike in the U.S., these decisions were ultimately left to the judgement of the athletes, who were thus faced with a moral conflict that, in an inverse way to Eric Liddle's dilemma in the film - his resistance to state pressure to run on Sunday - pitted the individual against the nation (Jeffreys 2012: 170). In working through this conflict, the film negotiates a distinctly British solution to the political impasse, based upon the moral fortitude of the athletes. This solution, while grounded in traditional notions of Britishness, serves to reimagine Britain as a cultural influence on contemporary global politics. Through the beach sequence, Chariots internalises this British alternative to American military power and, 
furthermore, with the film's international success, it was able to exercise this alternative cultural power on the global stage - a process that would reach its apex with the London Olympics of 2012.

We have made much thus far of the significance of the West Sands sequence; however, the sequence was in fact not initially imagined as a framing device. Early drafts of the script reveal an opening sequence that more directly addresses the political context in which the film was made: the filmmakers originally intended to present instead the 1980 Olympics as a framing device (Welland 1980: 1). Chariots was to begin in contemporary London, where through a TV in a shop window, one would spy a gold medal being awarded to an East German athlete, 'erect - bland - smiling a practised smile, programmed'. The camera would then pull back to reveal his teammates - with the silver and also bronze - 'cast from the same mould. They stand - a triumphant, manufactured trio' (Welland 1980: 1). At a moment of intense political crisis, when nations were constructed and pitted against one another as part of 'East' and 'West', the script presents these national representatives as 'manufactured' - by ideology and, as history has taught us, mass doping programs. From this opening shot of the contemporary victorious East Germans, the film would next move to Harold Abrahams's Christian memorial service in 1978, and then on to the flashback of the beach sequence. Similarly, at the end of the film, the script neatly flashes forward from the 1920s to Abrahams's service, after which the mourners would exit, and the TV would return as the final shot, now showing 'a weeping East German athlete who's just tasted bitter and disastrous defeat. He's inconsolable' (Welland 1980: 138). Against the Eastern bloc of televised athletes that bracket the unrealised opening and closing of the film's script, Abrahams is presented as the Anglicised, British ideal who is both an individualised star and also integrated into a team and nation that is harmoniously unified through moral fortitude across diverse regional, class and ethnic divisions. 
While the members of the British team function within the film as individuals, operating as part of a nation that is working not under state objectives but under an inherent moral code, the American team by contrast train as a collective, with its athletes professionalised and like the East Germans industrially 'cast from the same mould'. In its implied connection between contemporary East Germany and the emerging international power of America in the 1920s - between East and West - the film provides a distinct British position as a response to the contemporary international crises; a position that is, like the conflicts, born out of failed colonial endeavours. Chariots looks back to the height of the British Empire - or perhaps more accurately, to the moment when Britain's imperial progress was first checked by America's burgeoning internationalism - yet it does not advocate a nostalgic return to colonial or militaristic politics. Rather, the film imagines a post-imperial identity that, in its way, negotiates multiculturalism with British heritage.

The contemporary framing sequence imagined in the script, however, did not transfer to the screen. After shooting the exterior scenes for the opening and closing in London, Hudson and Puttnam determined during editing that the window footage was ineffective, so they cut the TV reference to the 1980 Games and returned instead in the finale to the beach scene, replaying it with Vangelis's score. In so doing, they substituted the contemporary international context with the displaced locale of St Andrews as Broadstairs, looking not to the present Olympics but to the past. In this way, the aesthetic work of the film itself through crafting out of the British landscape a timeless, Romantic style of representation that matches the moral fortitude of its heroes - also participates in the film's ideological move, by honing a pictorial look that was marketable internationally, particularly as it came to define the heritage cycle of the 1980s and 1990s.

These editing and stylistic manoeuvres ultimately proved even more successful than the polemically scripted and historically determined opening. In subtly reworking Britain's 
Romantic past, the film provides a malleable yet timeless way for Britain to exercise international influence based on a stylized sense of moral rectitude rather than military action, as in Operation Ajax. In turn, the film, most recognisably through the beach sequence, offers an enduring, and frequently recycled, ideological representation of Britishness at a moment when the nation was in danger of crumbling politically as well economically, as impotent as at any moment in its history.

As we have traced through the ideological moves inherent in Chariots of Fire, film's cultural capital has assumed an expanded geopolitical role over the past three decades. Returning now to Welland's speech, with its culturally imperialistic tone, his words invite comparison with those uttered to a global audience by Sebastian Coe at the closing ceremony of the Olympics on 9 September 2012. 'Finally, there are some famous words you can find stamped on the bottom of a product', Coe concluded, 'Words that, when you read them, you know mean high quality, mean skill, mean creativity. We've stamped those words on the Olympic and Paralympic Games of London 2012. London 2012 - Made in Britain'. There is a notable shift in tone here from 'the British are coming' in 1982, as Coe's comments now celebrate and champion Britishness as a cultural commodity.

If we return once more to the St Andrews beach, we can see how this isolated single sequence - displaced in space and time - is imbued with values and ideals that can be transferred across entirely different global contexts. While the sequence, with its slow motion movement across the spectacular and historical British landscape, may invite a conservative nostalgia, the film, as we have shown, complicates traditional national readings. As James Chapman and others have argued, the film was initially read from both sides of the political spectrum: as pro or anti-Thatcher, and as a nostalgic celebration of an Empire past or a postimperial challenge to recalcitrant social and racial structures (Chapman 2005: 270-271). What is also of vital significance is how and why this sequence continues to be reworked, 
whether preserving and channelling its prestige on a local level, modernising its notion of social and racial inclusion on a national level or monetising its values for a global audience. The film, and in particular the Romantic sequence on the West Sands beach of St Andrews, is mutable, constantly reworked and reinterpreted for different places, politics and times. This is what makes the clip allegorical, and valuable as cultural capital. The duality - conservative, nostalgic or liberal, multi-ethnic - speaks to the complexities inherent within the film, ensuring that the sequence can continue to be worked locally, nationally, and globally. It is the film's inherent pliability in negotiating these readings that has positioned it as a frontrunner in cinema's transformative field of cultural production. 


\section{Acknowledgements}

The authors would like to acknowledge Sarah Street for her generous feedback, David Puttnam and Donald Macgregor for providing interviews, Chelsea Wessels for her research assistance and BFI Special Collections for additional materials. The piece is derived from research conducted as part of the Cinema St Andrews project (http://cinemastandrews.org.uk).

\section{Figure Captions}

Figure 1: Mr Bean in 'a performance of Chariots of Fire' at the opening ceremony of the London Olympics 2012, video still.

Figure 2: David Octavius Hill, 'View of St Andrews, seen over the North Sands; man standing with horse', ca. 1846. Courtesy of Special Collections, University of Glasgow.

Figure 3: The filming of Chariots of Fire on the West Sands beach, St Andrews. Image courtesy of St Andrews Preservation Trust Museum.

\section{References}

Bandelj, N. and F. Wherry (eds) (2011) The Cultural Wealth of Nations. Stanford University Press.

Bourdieu, P. (1986) 'The Forms of Capital', in Richardson, J. G. (ed.) Handbook of Theory and Research for the Sociology of Education. New York: Greenwood Press, pp. 241258.

Chapman, J. (2005), Past and Present: National Identity and the British Historical Film, London: I. B. Tauris.

Crawford, R. (2011), The Beginning of the End of the World: St Andrews, Scandal and the Birth of Photography, Edinburgh: Birlinn. 
Dickinson, M. and S. Street (1985), Cinema and State: The Film Industry and the Government, 1927-84. London: BFI Pub.

Higson, A. (2003) English Heritage, English Cinema: Costume Drama Since 1980. Oxford: Oxford University Press.

Higson, A. (2006) 'Re-Presenting the National Past: Nostalgia and Pastiche in the Heritage Film', in Friedman, L. D. (ed.) Fires Were Started: British Cinema and Thatcherism. 2nd revised ed. London: Wallflower Press, pp. 91-109.

Jefferys, K. (2012), Sport and Politics in Modern Britain: the road to 2012, New York: Palgrave Macmillan.

Macgregor, D. F. (2010), Running My Life: A Man's Lifelong Run in Search of Contentment, St Andrews: Pinetree Press.

MacKenzie, J. M. (1984), Propaganda and Empire: The Manipulation of British Public Opinion, 1880-1960, Manchester, U.K.: Manchester University Press.

Martin-Jones, D. (2009), Scotland: Global Cinema: Genres, Modes and Identities, Edinburgh University Press.

Martin-Jones, D. (2014). 'Film tourism as heritage tourism: Scotland, diaspora and the Da Vinci Code (2006)'. New Review of Film and Television Studies, 12 (2). pp. 156-177.

'Olympic Torch: Handover on Chariots of Fire Beach' (2012) BBC, 13 June, sec. UK <http://www.bbc.co.uk/news/uk-18420480>, accessed 13 September 2013.

Street, S. (2009), British National Cinema, New York, NY: Routledge.

Throsby, D. (2001) Economics and Culture. Cambridge, U.K.: Cambridge University Press.

Welland, C. (1980), 'Chariots of Fire, $2^{\text {nd }}$ Draft', item 12, The David Puttnam Collection, BFI Special Collections.

\section{Notes}

1 http://www.digitalspy.co.uk/displayarticle.php?id=397652 (accessed 19 September 2013). 
${ }^{2}$ http://www.thesun.co.uk/sol/homepage/features/4030427/Lets-make-it-Great-Britain.html (accessed 19 September 2013).

3 https://www.gov.uk/government/news/turning-the-games-into-gold-governmentannounces-almost-10-billion-economic-boost-from-london-2012 (accessed 19 September 2013).

${ }^{4}$ http://cinemastandrews.org.uk/production/david-puttnam-on-st-andrews/ (accessed 19 September 2013).

${ }^{5}$ http://cinemastandrews.org.uk/production/david-puttnam-on-st-andrews/ (accessed 19 September 2013).

${ }^{6}$ http://www.fifetoday.co.uk/news/local-headlines/olympic-spotlight-shines-on-st-andrews1-2445452 (accessed 19 September 2013).

${ }^{7}$ http://cinemastandrews.org.uk/production/david-puttnam-on-st-andrews/ (accessed 19 September 2013).

${ }^{8}$ David Martin-Jones has also usefully highlighted the proactive role of the British Tourist Association and the Scottish Screen Locations office (now run through Creative Scotland) in bringing a plethora of Indian productions to Scotland at the turn of the twenty-first century as a means of increasing production units, box office revenue, and finally tourism in Scotland (2009, 67-70). These productions build upon St Andrews's appearance in Chariots of Fire, using Scottish landscapes as unspecified, fictional and often times fantastical locations.

${ }^{9}$ http://www.dailyrecord.co.uk/news/scottish-news/eric-liddell-lessons-for-kids-1187436, (accessed 13 September 2013) 
${ }^{10} \mathrm{http}: / /$ cinemastandrews.org.uk/production/david-puttnam-on-st-andrews/ (accessed 19 September, 2013). 